\title{
Democracy, Democratic Governance and Nigeria's National Development: An Analysis of the Intricate Relationship
}

\author{
Umar, Mohammed Bello PhD Mallam Isa Suraj \\ Department of Political Science, Federal University DutseJigawa State, Nigeria \\ Department of Economics and Development Studies, Federal University Dutse \\ Jigawa State, Nigeria.
}

\begin{abstract}
MOST of the answers to the question as to whether there is link between democracy and development will of course depend on how one perceives and defines 'development'. If one is to follow and also adopt an understanding that denote development as 'freedom' - a broad and perhaps an ideal definition that incorporates not only economic indicators but also freedoms like human and political rights, social opportunities, transparency guarantees and protective security, then democracy is implicitly causative of development. Debates on a rights-based approach to development also are recently more focused more on participation, accountability, and other elements that are fundamentally similar to those values underlying substantive forms of democracy as indicated the narratives of the UNDP and other scholars the world over. This article is an attempt at closely reviewing these postulations citing globally acclaimed examples accessed from diversely available literature. Most of the inroads made on the subject are more closely related to the experiences of developing countries who are often more closely beamed as focus of study and analysis when it comes to examining the intricate linkage between democracy and development.
\end{abstract}

Key Words: Change, Democracy, Development, Governance, Modernization

\section{INTRODUCTION}

Understanding development in such a holistic way is of great value' Such an approach may however pose some conceptual problems. Defining the term development in relation to many of attributes inherent to democracy (including rights and accountability) makes it more difficult analytically to make a distinction between the two terms and to be able to unravel the nature of the relationship between them. It may be useful for this reason to adopt a somewhat narrower definition of the concept of development. Reflecting on Joseph Stiglitz (2003) postulation, development for the purposes of this paper may be understood as a 'transformation of society' that goes further than economic growth alone to include social dimensions like literacy, distribution of income, life expectancy, etc. - the variables captured and reiterated in the UNDP's human development index (HDI). Furthermore, development must include some dimensions of the (re)distribution of wealth as well (Leftwich 2005).

Once the value of democracy in its intrinsic form has been established, it is still very much worth asking the 'so what?' question: Does democracy make a difference? and if so, what kind of difference? The growing recognition of institutions as key factors in shaping (developmental) outcomes (e.g. Economic Commission for Africa 2005; Fritz and Rocha Menocal 2006 and 2007) and the movement of more poor countries towards democracy have both sharpened the essence, relevance and the stakes of this debate even further. Many of the questions fundamentally pondered include the following:

Does development lead to democracy, or is it the other way around? What are the institutional structures or mechanisms behind economic performance? Can democracy augment development, or are authoritarian governments better outfitted for that task? And is economic development obligatory in enabling democracies in the developing world to deepen and become reinforced and consolidated?

In order to shed more light on the topic under discourse, the concepts of democracy and development must be highlighted separately and distinctively. Consequently, the factors and theoretical explanations essential to the two concepts were also discussed in a different way. Similarly, the interaction between democracy and development was discussed in the subsequent sub-headings while possible theoretical patterns and delineation of the causality between development and democracy were established. Succeeding sub-heading elaborated on the assessment of development and democratic governance in Nigeria, which is also viewed as the main theme of the paper. Conclusions are also drawn on the basis of the performance democracies and autocracies in areas of development. 


\section{"DEMOCRACY" - A Conceptual Exploration:}

Generally, it is believed that in defining democracy, it could be regarded as deficient or incomplete if attention is not particularly focused on the popular definition propounded by the former President of the United States of America, Abraham Lincoln. He defined democracy as "government of the people, for the people and by the people". In other words, democracy is a system of government in which all the people of a state or a definable polity ... are involved in making decisions about its affairs, typically by voting to elect representatives to a parliament or similar assembly, or a system of government in which the supreme power is vested in the people and exercised by them directly or indirectly through a system of representation usually involving free elections that are from time to time held.

Larry Diamond postulated that democracy in the true sense of the word consists of four fundamental elements:

1. A political system for choosing and replacing the government through free and fair elections.

2. The vigorous participation of the people, as citizens, in politics and civic life.

3. Protection of the human rights of all citizens.

4. A rule of law, in which the laws and procedures apply equally to all citizens.

Equally, according to both the Universal Declaration of Human Rights and the Vienna Pacts and Declaration of 1993, democracy is a system whereby the whole of society can participate, at every level, in the decision-making process and keep control of same. Its foundation is the full observance of human rights. The promotion of those rights, respect of differences and of freedom of speech and thought are indispensable preconditions for democracy. There can be no democracy without an independent judicial system and without institutions that guarantees freedom of expression and the existence of free media. The power to legislate must be exercised by representatives of the people who have been elected by the people. Laws must therefore be implemented by legally responsible individuals, and the administrative apparatus must be accountable to the elected representatives.

In Direct Democracy, the citizens participate in the decision-making personally, contrary to relying on intermediaries or representatives. It gives the voting population the power to change constitutional laws, put forth initiatives, referendums and suggestions for laws, and give binding orders to elective officials, such as revoking them before the end of their elected term, or initiating a lawsuit for breaking a campaign promise. Representative Democracy involves the election of government officials by the people being represented. This system gives rise to presidential or parliamentary system of government.

Quite a number of modern democracies that are predominately representative in nature also heavily rely upon forms of political action that are directly democratic. These democracies, which combine the fundamental elements of representative democracy and direct democracy, are termed Hybrid Democracies, Semi-Direct Democracies or Participatory Democracies. Examples could be located in Switzerland and some U.S. states, where frequent use is made of referendums and similar other initiatives.

\section{DEVELOPMENT - A Definition:}

The World Bank (1985) in its current conception on 'development' implies the prominence of human rights, free market economy, democracy, gender equality, population and environmental control, thus, development is, therefore, about the issue of self-reliance; a self-generating and self-sustaining phenomenon. development, therefore, conceived in human term denotes the maximum satisfaction of basic human needs exemplified by adequate and descent food, water, electricity, shelter, education, modern social and infrastructural facilities.

\section{DEMOCRACY: Occurrence Factors and Theoretical Explanations:}

Traditionally, that democracy and democratization need preconditions is acknowledged by most social scientists. Their works were dedicated to discovering the primary preconditions for democracy; and factors that impact the occurrence, continuity, and breakdown of democracy. According to the work of Larry Diamond, Juan Linz and Seymour Lipset, there are ten identifiable "factors" facilitating and obstructing democratic development. These includes - legitimacy and performance; political leadership; political culture; social structure and socioeconomic development. Others are civil society, state and society; political institutions; ethnic and regional conflict; the military; and international factors (Diamond, et al. 1995, pp.9-52).

Dankwart Rustow (1970) has on the other hand, however, argued that national unity - where the vast majority of citizens in a democracy-to-be must exist and citizens must have no doubt or mental reservations as to which political community they belong to. This he concluded should be the background condition for democracy to effectively subsist. Many scholars are however in disagreement with Rustow because they believe national unity, or the unity of national identity, is not necessary for a political system or a state to move towards democracy; in contrast rather, the clash of national unity or the conflict of national identity might be resolved by the establishment of a body of functional democratic institutions. In other words, it is not national unity that leads to democracy, but democracy stimulates or generates national unity and a cogent national identity. 
Moreover, democracy or democratization might possibly take place without national unity, but the problem of unity is getting worse in the process of political change. For example, the case of Taiwan's democratization exhibits the divergence of national unity and the disagreement of national identity still persisting and remaining largely unsettled. In Taiwan's democratic transition even democratic consolidation is believed to be almost at the corner. This is equally the case in Nigeria where ethnic, tribal and religious differences have taken the centre stage in the country's journey towards genuine democracy.

\section{DEVELOPMENT: Determining Factors and Theoretical Explanations:}

Concerning theoretical explanations of development, there are basically three analytical approaches: modernization/culture approach; dependency theory, and institution/regime type approach. Basically, the proponents of modernization theory and the 'culturalist' proponents believe that constructing modernity and discarding tradition will go towards the stimulation of development; planting or transplanting the right cultural traits is believed to be largely helpful in promoting economic growth in developing countries. By building dichotomy of tradition-modernity ideal types of social organizations, scholars of modernization theory argue that the path towards development is to discard and overcome the elements, norms, and obstacles of a traditional society as reported Valenzuela and Arturo Valenzuela (1978).

Dependency theory emphasizes that the problem of underdevelopment is developing countries' external relations to the international system, in particular the West; and it rejects the basic assumption of modernization that "the unit of analysis in studying underdevelopment is the national society" again as Valenzuela and Arturo Valenzuela (1978) reiterated. The issue of development can only be understood in connection with its historical insertion into the worldwide political-economic system which emerged with the wave of European colonization of the world as argued a number of similar scholarly groups. This global system is thought to be characterized by the unequal but combined development of its different components.

In contrast to that, modernization and culture approach focuses on a national society; and dependency approach emphasizes the importance of a state's external relations with industrialized countries. The 'institutionalist' perspective also stresses the critical influence of institutions on development. This idea that eloquently speaks on the value of institutions has originally emanated from Douglas North. North has argued that institutions tremendously influence economic activities because "institutions provide the incentive structure of an economy; as that structure evolves, it shapes the direction of economic change towards growth, stagnation, or decline" (North 1991).

\section{DEMOCRACY AND DEVELOPMENT: A Case of an Intricate Relationship:}

Democracy and development are profusely known to be complementary, and they undoubtedly reinforce each other. The link between them is all the stronger because it originates in the aspirations of individuals and peoples and in the quantum of rights they enjoy. History has indeed shown that cases where democracy and development have been dissociated or disentangled have mostly resulted in dreary failure. On the contrary, also, the interlinking of democratization and development has often helped both of them to robustly take root. For if political democracy, in order to strengthen itself, needs to be complemented by economic and social measures that encourage development. Similarly, any development strategy would ultimately need to be ratified and toughened by several processes of democratic participation and facilitation in order to be implemented.Past studies and research activities have indicated at least five theoretical patterns of the causality between development and democracy. Dredging through several literatures related to the string of economic development and democracy in the process of democratization in developing countries, up to five possible theoretical models arguing the issue of the priority of development and democracy have emerged as cogently distinct:

In the first instance, the modernizationists, such as Seymour Lipset, have argued that economic growth leads to democracy, so that "development first, democracy later" (Lipset, 1959). Second, however, Samuel Huntington proposes an alternative explanation of the development of democracy from the perspective of "process" arguing that the outcome of economic development would lead to political decay; then the political system under instability would move towards democracy through and after institutionalization (Huntington, 1968). Third, in an apparent contrast to modernization theory, Bruce Bueno de Mesquita and George Downs discovered that in the case of China, the result of economic development would not lead to democracy because authoritarian regimes and autocracies around the world show people that they can enjoy the benefits of economic development on the one hand and avoid political liberalization on the other (Mesquitaand Downs, 2005). Their findings run counter to the argument of modernizationists that democracy is the necessary result of economic development. Fourthly, scholars who support "democracy first, development later," such as Joseph Siegle, Michael Weinstein, and Morton Halperin, argue that democracies consistently outperform nondemocracies on most indicators of economic and social well-being, so that promoting democracy should be prior to expanding economic development in developing nations as Siegle,Weinstein (2004) and Halperin 
(2005) narrated. And some other scholars, such as Adam Przeworski and Fernando Limongi, fifthly argued that although politics indeed influence economic performance, the impact of regime-type is not significant on the economic growth of states; and people do not clearly know whether democracy improves or confines economic development (Przeworski and Limongi, 1993; Przeworski, Alvarez, Cheibub, and Limongi, 2000).

\section{Other Theoretical Patterns of the Causality Between Development and Democracy: a) Modernisation Theory and the Emergence Of Democracy -}

In the 1960s and the 1970s, an argument that prominently gained considerable eminence in mainstream academic and policy circles was that democracy was more likely to emerge in countries with high or higher levels of socio-economic development, a position Lipset (1959) Almond and Verba (1963) and Moore (1966) elaborated and similarly maintained. Reinforcing on Lipset's seminal analysis (1959), which stresses at one point that economic wealth is 'an initial condition for democracy, many analysts and scholars interpreted this correlation as implying that development was a precondition for democracy. This approach to democratization understood the emergence of democracy as a consequence of the transformation of class structure, the emergence of a bourgeoisie pattern of economic development, glaring increase of urbanization, the prior development of democratic values, and other cultural and religious factors. Thus, according to this interpretation, the emergence of democracy is endogenous to the process of economic and social development, thus, further indicating a simple, linear progression towards modernization that inevitably culminates in democratization. In other words, once a nondemocratic regime acquires a certain level, or 'threshold,' of economic development and social maturity, it will inevitably become a democracy. According to the modernization approach, then, the appearance of democracy should be seen as the crowning achievement of a long process of modernization, or as a luxury that affluent countries can (finally) afford.

\section{b) "Democracy First, Development Later" or "Development First, Democracy Later" -}

The core of the argument that democracy help towards development facilitation rest on some of the key institutional features of democratic systems - namely its accountability mechanisms and its checks and balances provisions. These features play an essential role in limiting the abuse of executive and state power more broadly, and through elections and other processes, they also provide a predictable (in terms of rules, not outcome), transparent, periodic, and reliable system of rewards and punishments. According to Sen (1999a), for example, it is these institutional characteristics visible within an effectively functional democracy that explains why for instance famines have never occurred in democratic systems. In a comparative analysis of policy reform in Central Europe after the transition to democracy in 1989, David Stark and László Bruszt also reported that 'executives that are held accountable by other state institutions and held in check by organized societal actors produce more effective development policies.

Much of the empirical data or evidence underneath the 'thesis' that authoritarian regimes are in general more effective than democratic ones in promoting rapid development comes from the examples of the so called East Asian Tigers (Korea, Taiwan, Hong Kong and Singapore), where the state in each case oversaw, led and closely directed a process of rapid economic growth and radical socio-economic revolution from the 1960s to the 1990s. More recently, China and Vietnam have also been used as important showcases in favor of this colossal argument. As many analysts have recommended (Evans, 1995; Haggard, 1990). The secret of these (East) Asian developmental strides lies in what Peter Evans has aptly described as their 'embedded autonomy', or their institutional capacity to promote developmental goals without being 'captured' by particularistic interests while remaining 'embedded' in society through a concrete set of social ties that binds the state to society and provides institutionalized channels for the continual negotiation and renegotiation of goals and policies' (Evans 1995). However, as reflected by these (East) Asian experiences, 'embedded autonomy' can be a highly exclusionary arrangement, where the state is linked not to society at large, but to dominant groups within it, especially among the industrial class and as maintained Rocha Menocal (2004).

\section{c) Political Order and the Change Process -}

In disparity to the path of "direct evolution" towards democracy from economic development supported by the modernization school, Samuel Huntington in his Political Order in Changing Societies (1968) proposes an alternate explanation of "indirect evolution" from economic development to democracy. While investigating domestic political change since the end of the World War II, in numerous Latin American countries, Huntington argues that although economic growth creates preconditions and opportunities for developing countries to evolve toward democracy, political structure or political transformation under authoritarian and totalitarian regimes do not necessarily keep pace with what he described as economic "takeoff," the requests for open political participation, and the demands of a dramatically changing society. "Political decay" and instability take place since these regimes do not have institutions to "digest" or to respond to these requests and the demands of a dramatically changing society. "Political decay" and instability also take place 
since these regimes do not have institutions to "digest" or to respond to the requests and demands from discontented middle classes and social groups (Huntington 1968 and Pion Berlin 2001, p.5). In order to deal with the problems of political instability and societal disorder, middle classes often tend to turn to the military to take over power and to restore 'normalcy'. This is also why we could see a number of military coups and praetorian administrations in developing countries. However, political decay and instability would just take place in the early stage of the process of transition; in the later stage Huntington argues that authoritarian and totalitarian regimes could keep moving towards democracy and may reach same through "institutionalization" Huntington (1968) further argued.

\section{d) Development not a Catalyst to Democracy -}

The third theoretical postulation of the causality between development and democracy is enshrined in the expression that "development does not lead to democracy". Running counter to "economic development leads to democracy", Bruce Bueno de Mesquita and George Downs argue that over the past fifty years a number of authoritarian regimes have experienced dramatic economic development without corresponding political liberalization usually associated with democracy; in contrast, political elites' power and positions in these countries are more strengthened and more consolidated through the benefits of economic development. Empirically, the cases of China and Russia show people that not only do authoritarian regimes generate extensive economic growth, but they also figure out some "strategies" to avoid political liberalization. They also criticized the modernizationists and development theorists consistently ignoring and understating the ability of authoritarian regimes to prevent the demands of democratization a position adequately chronicled by de Mesquita and Downs (2005).

\section{e) "Democracy does not matter in Development" -}

The fifth theoretical explanation of the causality between democracy and development is "democracy does not matter in development" even though politics is indeed noted as stupendously influential on the economy. The impact of regime types, democratic or non-democratic, on economic performance of nations is still obtusely controversial. Przeworski and Limongi reviewed the arguments that relate regimes to economic growth focusing on critical issues such as property rights, pressures for immediate consumption, and the power and 'autonomy' of dictators. Although most likely many will agree with the fact that protection of property rights could foster economic growth, there is, however, a lingering debate on whether democracies or dictatorships better secure citizens' property rights. Secondly, the primary reason why a democracy may be considered to be a hindrance to economic development is the enormous pressure for immediate consumption under its institution; and this leads to reduction in real sector investment and therefore inimical to growth and development.

\section{Development and Democratic Governance in Nigeria - An Assessment:}

One of the most robust findings of the last two decades of intense research on democratization is that the establishment and durability of democracies are strongly correlated with economic growth and development. This is based on the wisdom that democracies enjoy institutional advantages that are vehemently supportive of economic development and which has also made it more possible for genuine economic change to take place. Democracies are found to be most enriching to people's lives through the granting of political rights and a more effective pursuits of better and perhaps more welfare oriented programs and projects (Tortenson: 1994, Sen: 2001, Heitger: 2004, Root: 2005, Sharma: 2007)

Nigeria has, thus, recorded significant success through participatory democracy whereby women groups participated with a unified voice in the Constitution Review Process. By developing a joint memorandum, these groups established a clear set of demands that addressed specific clauses in the Constitution. They recorded a significant achievement with the inclusion of some of their issues in the House of Representatives and Senate reports. Specific issues included the rights to education, health and housing, and also addressed the issue of 'indigeneship' and how it affects the ability of women to hold representational positions in Nigeria.

Notwithstanding the observations that the elections which brought Olusegun Obasanjo to power in 1999 and again in 2003 were condemned as unfree and unfair, Nigeria has shown monumental improvements in her attempts to tackle corruption and to hasten development. President Obasanjo showed some willingness to fight corruption, but was, however, accused by others of colossal corruptive activities. Umaru Yar'Adua of the Peoples Democratic Party came to power in the general elections of 2007 - an election that was similarly witnessed and condemned by the international community as being massively fraught with irregularities.

Nigeria on a global scale has been classified as an emerging market, and is viewed as rapidly approaching middle income status with its abundant supply of resources, a well-developed financial, legal, communications, transport sectors and a robust stock exchange, the Nigerian Stock Exchange, considered widely as the second 
largest in Africa. Nigeria is also ranked 37th in the world in terms of GDP (PPP) as of 2007. Due to the adoption of democracy, Nigeria has become the United State's largest trading partner in sub-Saharan Africa and used to supplly a fifth of US's oil i.e. $11 \%$ of its total oil imports. Currently, Nigeria is the 50th-largest export market for U.S. goods and the 14th-largest exporter of goods to the U.S. while the United States remains the country's largest foreign investor. Previously, economic development had been hindered by years of military rule, corruption, and mismanagement, but the restoration of democracy and subsequent economic reforms has successfully put Nigeria back on track towards achieving its full economic potential as one of the major economies in Africa.

During the oil boom of the 1970s, Nigeria accumulated a significant foreign debt to finance major infrastructural investments. With the fall of oil prices during the oil glut in the 1980s, Nigeria struggled to keep up with its loan payments and eventually defaulted on its principal debt repayments, limiting repayment to the interest portion of the loans. Arrears and penalty interest accumulated on the unpaid principal which increased the size of the debt. However, after negotiations by the Nigerian authorities, in October 2005 Nigeria and its Paris Club creditors reached an agreement in which Nigeria repurchased its debt at a discount of approximately $60 \%$. Nigeria used part of its oil profits to pay the residual $40 \%$, freeing up at least $\$ 1.15$ billion annually for poverty reduction programmes. Nigeria made history in April 2006 by becoming the first African Country to completely pay off its debt (estimated at $\$ 30$ billion) owed to the Paris Club of creditors. These are all considered as some of the advantages of democratic governance.

Some of the developmental milestones recoded in Nigeria under democratic space may be summarized to include the following:

(1) The advent of GSM in 2001, dramatically revolutionized the information and communications landscape;

(2) The railway linking Lagos, Nigeria's commercial capital, to Kano, the country's second largest city, was reopened after more than ten years;

(3) Reducing Nigeria's dependence on crude oil as its major export, to "only" $70 \%$ of its exports through a series of diversification efforts;

(4) The passage of the Freedom of Information (FOI) Act in 2011 after 12 years of foot-dragging is a democratic feat. With the ICT revolution and Web 2.0 tools, online news and blogs are now a dime a dozen, conveying information ranging from the deathly accurate, to the wildly speculative to the downright absurd. The Press Freedom Index 2013 ranks Nigeria 115 out of 179 countries, an improvement from its position last year at 126; Books such as Olusegun Adeniyi's Power, Politics and Death, chronicling the watershed events during the Yar'adua administration; Dr. Ngozi Okonjo Iweala's Reforming the Unreformable: Lessons from Nigeria; Professor Dora Akunyili's War Against Counterfeit Medicine, Malam Nasir El-Rufai's The Accidental Public Servant have been most informative, revealing and above all most controversial;

(5) The Nigerian movie industry which includes Nollywood and Kannywood, the Hausa movie industry in Northern Nigeria has grown exponentially in the last decade. Nollywood is now the believed to be 3rd largest movie industry in the world after Hollywood and Bollywood; recording an average of $7.4 \%$ economic growth over the past decade. The IMF has indicated that Nigeria is one of the fastest growing economies in not just Sub-Saharan Africa but in the world. Recent reports have confirmed that Nigeria has overtaken South Africa as the largest economy on the African continent.

From the view point of the aforementioned reasons, a clarion call was severally made for the nations of the world especially the emerging ones to embrace democracy, given that it is perceived to be fundamentally facilitative of development. Given that it is not universally accepted and practiced, democracy has faced a lot of ideological contradictions, with criticisms. In spite of its widespread nature globally, there still exist difficulties in adopting and translating its holistic values into a framework for sustainable development in most parts of the world. This could be attributable to many factors, which includes poor development of democratic institutions, ideological confusion and misconceptions, as well as others.

\section{CONCLUSIONS:}

An analysis of the causal link between democracy and development has remained controversial for a long time. For most of the twentieth century, conventional wisdom has however, contended that autocracies are better able to marshal the resources necessary to promote economic development than are democracies, and that a certain level of economic development is necessary for democracy to take hold and thrive in a country. This view deserves a re-examination more especially in the context of the post-Cold War era. Morton H. Halperin, Joseph Siegle, and Michael Weinstein made such a review on the subject in their book The Relationship between Democracy and Development: Implications for Policy published in 2003 and their results presented some interesting implications for further research and scholarship.

When the countries of the world are examined as a whole, democracies do perform better in terms of economic development than do autocracies or mixed polities. The debate concerns developing countries - 
specifically, can democracies develop as low income countries; can poor countries democratize; and does democracy among low income countries make any difference for their development success? These are the questions that have become more often asked in addition to being extensively widespread.

Furthermore, a series of researches and hypotheses have postulated that, there has been no advantage for autocracies over democracies for the past 40 years in terms of development. Both democracies and nondemocracies in developing countries have grown in terms of their GDP. When East Asia is removed from these selection of countries all indicators are pointing to the fact that democracies have actually performed better growing at $0.5 \%$ per capita per year faster than autocracies and mixed polities. What is more, there is no data on about $25 \%$ of autocracies - countries such as North Korea, Iraq, Afghanistan, and Cuba - so actual growth figures for autocracies would likely be substantially lower if the performance of these additional countries were included.

Not just simply growing at a faster rate, democracies have outperformed autocracies in the stability and consistency of their growth. It is reported widely that up to 80 worst economic performers of the last 40 years in the world reveal that all but three have been autocracies. In addition, democracies have performed substantially better than autocracies in the social welfare dimension of development such as in the area of life expectancy, child mortality, literacy rates, etc.

At this stage it is important to note that there has been a variety of development experiences among democracies. This can be attributed to the differing success with which any country can develop institutions of accountability - checks on the chief executives and heads, separation of politics from the civil service, independence of the judiciary, freedom of the press, and independence of the private sector, property rights for example - which are the very foundation of democratic systems of governance. Both autocracies and democracies that have developed these institutions have obviously had better rates of economic growth and development than countries without well established institutions of accountability. There are indeed some autocracies that have performed better than some democracies; the East Asian "tigers" have elaborately fallen into this category.

Despite the overall positive performance of democracies over autocracies in development, there has been no preference given to democracies over the past 40 years in the dispersal of development assistance. The same has been true with debt relief, even though new democracies - countries that have recently transitioned from autocratic rule - have often inherited debt that is as high as $23 \%$ of their GDP, a figure higher than that for most low income countries. This problem is further compounded by the apparent realization that the lack of a "democracy dividend" can undercut popular support for democracy.

\section{REFERENCES}

[1] Almond G. A. and Verba, S., 1963. The Civic Culture: Political Attitudes and Democracy in Five Nations, Princeton, NJ: Princeton University Press.

[2] Bardhan, P., 'Democracy and Development: A Complex Relationship'. Berkeley, CA: University of California, Berkeley.

[3] Bates, R., 1981. Markets and States in Tropical Africa: the Political Basis of Agricultural Policies, Berkeley, CA: University of California Press.

[4] Boucher, R. (2000): 'Towards a Community of Democracies'. Press Statement, Washington, DC: US State Department, Office of the Spokesperson.

[5] Bratton, M. and van de Walle, N.,1994. Democratic Experiments in Africa: Regime Transitions in Comparative Perspective, Cambridge: Cambridge University Press.

[6] Carothers, T. (2002) 'The End of the Transition Paradigm', Journal of Democracy 13(1):1

[7] Diamond, L., Juan J. L, and Seymour M., L. (1995): "Introduction: What Makes for Democracy", in Politics in Developing Countries: Comparing Experiences with Democracy, eds. Boulder: Lynne Rienner Publishers.

[8] De Mesquita, Bruce Bueno and George Downs (2005): "Development and Democracy" in Foreign Affairs 84(5): 77-86.

[9] Dos Santos, Theotonio. 1970. "The Structure of Dependence," in The American Economic Review, 60(2): 231-236.

[10] Firebaugh, Glenn (1992): "Growth Effects of Foreign and Domestic Investment", American Journal of Sociology, 98(1):105-30.

[11] Sen. A, 2001. "DEMOCRACY as a Universal Value" in The Global Divergence of Democracies ed. Larry Diamond and Marc F. Plattner, Baltimore MD, John Hopkins University Press.

[12] Sharma, S.D., 2007. "Democracy, Good Governance and Economic Development", in Taiwan Journal Of Democracy, Vol 3, No 1, pp 29-62.

[13] Torstensson, J., 1994. "Property Rights and Economic Growth: An Empirical Study", in Kyklos 47. no 2: 231-247 